\title{
Restoring the natural smile with minimal intervention
}

\author{
Fernando Pinheiro Fialho ${ }^{a}$, Leily Macedo Firoozmand ${ }^{b}$
}

\begin{abstract}
Objective: Depending on the degree of saturation and time that pigments have been in the dental tissue, teeth with severe color change may have a poor prognosis for bleaching treatment.

Case Report: In the reported case, after a careful clinical history and evaluation of clinical case a conservative treatment with composite resin restoration was carried out on superior central incisor with severe darkening. Direct composite resins with different opacity and translucency in association with resin pigments and a conservative technique were used guaranteeing a minimal intervention and giving a natural aspect to the tooth. The use of pigments made possible less wear of dental structure for insertion of the composite resin, mimetizing the restored tooth with the corresponding teeth.

Conclusion: It was concluded that in some cases where indirect restorations would be indicated, when different kinds of dental materials and techniques are applied, direct restorative treatment would be a great option for esthetic restorations.
\end{abstract}

Key words: Composite resins; dentin-bonding agents; dental esthetics

\section{Restaurando o sorriso natural com mínima intervenção}

\section{RESUMO}

Introdução: De acordo com o grau de saturação e tempo em que os pigmentos permanecem impregnados nos tecidos dentais, dentes com severa alteração de cor podem apresentar um prognóstico ruim para a realização do tratamento clareador.

Caso Clínico: No caso clinico apresentado, após uma minuciosa anamnese e avaliação do caso clinico foi proposto a realização de um tratamento restaurador conservador com resina composta no incisivo central superior que apresentava severo escurecimento da coroa dental. Diferentes Resinas compostas com variados graus de opacidades e translucidez foram utilizados, em associação a pigmentos resinosos, permitindo a realização de uma técnica conservadora e uma mínima intervenção, garantindo um aspecto natural ao dente. 0 uso de pigmentos associados à resina composta possibilitou um menor desgaste da estrutura dental e inserção da resina composta, mimetizando o dente restaurado ao seu dente homólogo.

Conclusão: Foi possível concluir que em alguns casos extensos onde restaurações indiretas poderiam ser indicadas, tratamentos restauradores diretos podem ser uma grande opção para as restaurações estéticas quando diferentes tipos de materiais restauradores e técnicas são aplicadas.

Palavras-chave: Resinas Compostas, Adesivos dentinários, Estética Dentária.

\author{
Restorative Dentistry, Brazilian Dental Association \\ ABO-MA, São Luis - MA, Brazil \\ b Professor, Department of Dentistry I, Federal \\ University of Maranhão, São Luis, MA, Brazil
}

Conflict of Interests: The authors state that there re no financial and personal conflicts of interest that could have inappropriately influenced their work.

Copyright: ( 2016 Fialho and Firoozmand licensee EDIPUCRS. 


\section{INTRODUCTION}

The smile harmony has become an important aspect to be considered in Esthetic Dentistry, especially with the development of adhesive systems for restoring dental structures. Actually, with the advancement of Cosmetic Dentistry there is a current quest for harmony with natural smile. The esthetic restorative treatment has a positive effect on patients' self-esteem $[1,2]$. Thus, the restorative treatment has become more than functional in esthetic restoration of the dental structure; it also restores the patient's social relations.

Severe discolored and malformed dentition in most cases can be treated with composite resin, laminate veneers and all-ceramic crowns. When indirect treatment is proposed, close cooperation between the restorative dentist and the laboratory technician is important [3]. However, with the development of composite resin and adhesive techniques it is possible to make direct esthetic restorations, applying full knowledge of the dental materials science, and in some cases, without laboratory.

The optical phenomena of natural teeth in the incidence of light to reproduce an image is captured and assimilated. Today's composite resins have optical and physical characteristics that have consolidated their clinical indications. The predictable application and success of restorative materials depends on the clinician's understanding of the material properties as well as the clinical requirements involved in their use. Another important point that should be considered is the identification of the characteristics of the natural tooth [4].

The direct composite resin systems are suited for stratifications, or layering of various opacities and colors of dental composites. These resources offer dentists the opportunity to reproduce details of natural teeth with better cosmetic results than many indirect esthetic restorations [5].

It has been verified by Terry [6], 2003 that the understanding of tooth morphology, restorative material selection, color options, and the physical properties of light, allow optimally esthetic restorations to be predictably achieved.

Thus, the objective of this study is to present a clinical case that after a thorough history and clinical examination, a direct composite resin restoration was made. The use of different pigments, tints and opacity was a solution for severe tooth discoloration giving a natural appearance to the tooth by applying a more conservative technique.

\section{CASE DESCRIPTION}

A 35 year-old man presented himself for the evaluation in the clinic of Specialization of Restorative Dentistry, at Brazilian Dentistry Association (ABO), São Luis-MA, to restore the esthetical harmony of his smile. The patient had a severe darkening of the maxillary central right incisor (Figure 1). After general medical and dental histories were reviewed it was observed that the patient had dental darkening for more than 10 years.
During the clinical examinations, no pain was reported when the tooth were subjected to physical or thermal stimuli. The periapical radiography revealed an intact periodontal ligament space and a solid bone associated with a suitable endodontic treatment.

The analysis and study of color, shape and size of counterpart teeth guided the confection of direct veener. Various principles come into play in smile design, including the personal interpretations and desires of the patient and the dentist. The hue, chroma and value of different part of the tooth were chosen before the modified rubber dam isolation was performed. In order to help the cervical ending of the preparation, a retractor cord 000 Ultrapack - Ultradent (Indaiatuba, SP, Brasil) inserted in the gingival sulcus was used (Figure 2).

A reduced wear $(0,8 \mathrm{~mm})$ on the tooth buccal surface was made. The delimitation of the cervical margin of the preparation was carried out with the aid of a diamond round bur 1014 (KG Sorensen, Cotia, SP, Brasil). Afterwards, the vertical orientation grooves were made on the buccal surface using the drill stem conical diamond tipped 2135 (KG Sorensen, Cotia, SP, Brasil). In sequence, an even wear of the buccal surface of maxillary central incisor was obtained. A smooth prepare surface was achieved by carrying out the finishing using the fine 2135F (KG Sorensen, Cotia, SP, Brasil) and ultrafine 2135FF (KG Sorensen, Cotia, SP, Brasil) diamond burs (Figure 3).

The tooth was etched with $37 \%$ phosphoric acid gel for $15 \mathrm{~s}$. The acid was rinsed off thoroughly for $15 \mathrm{~s}$ using air and water spray. Excess water was blotted with an absorbent paper to avoid desiccation. To ensure proper dentin and enamel bonding, the adhesive system Adper ${ }^{\mathrm{TM}}$ Single Bond (3M ESPE) was applied according to the manufacturer's instructions. The Optilux 501 (Demetron - Kerr) was used for curing of all resin materials, following the manufacturer's instructions.

The first increment $(0,4 \mathrm{~mm})$ of microhybrid composite resin OW Opallis (FGM, Joinville, SC, Brasil) was inserted to mask the extreme darkening of dentin and properly curing it. The ochre, light brown and red pigments were selected from Tetric Color Kit (Ivoclar-Vivadent, Barueri, SP, Brasil). From these pigments, the ochre, light brown and red were mixed in the ratio $4: 2: 1$ obtaining a color similar to the dentin structure. The color obtained by mixing the pigment was applied with brush no 1 Cosmedent INC (Chicago, Ilinóis, EUA) on the opaque resin. The hue and chroma could be controlled by modifying the degree of saturation of the dental tissues according to the area of the tooth (Figure 4).

The tooth venner of central incisor was performed copying the dental tissue counterpart simulating the optical effects present in the tooth structure. Thus, in the incisal third of tooth blue pigment to simulate the enamel blue opalescent halo was applied. The cervical and central areas in the central incisor crown were highlighted with the use of the pigment. An existing crack in the tooth enamel was simulated using white pigment inserted with a brush $\mathrm{n}$ - 1 Cosmedent INC (Chicago, Ilinóis, EUA) (Figure 5). The use 
of pigments permitted a minor wear of the tooth structure and, therefore, placement of smaller thickness of restorative material.

A final thin layer $(0,3 \mathrm{~mm})$ of microfill A2 Durafill Vs (Heraeus Kulzer), composite resin was applied on the tooth to reproduce the enamel structure.

Afterwards, the initial finishing was done with finegrained diamond bur 2135F (KG Sorensen, Cotia, SP, Brasil). Fine granulated diamond burs and polishing disks

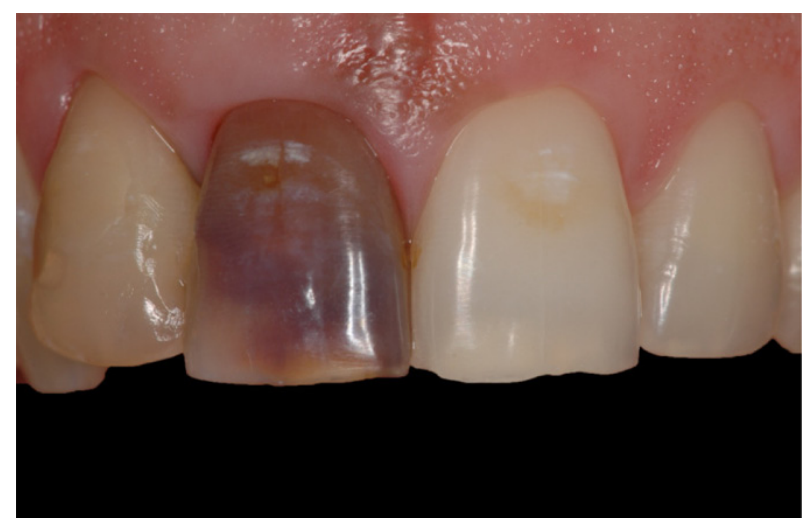

Figure 1. Initial clinical aspect $f$ the central incisor with severe browning.

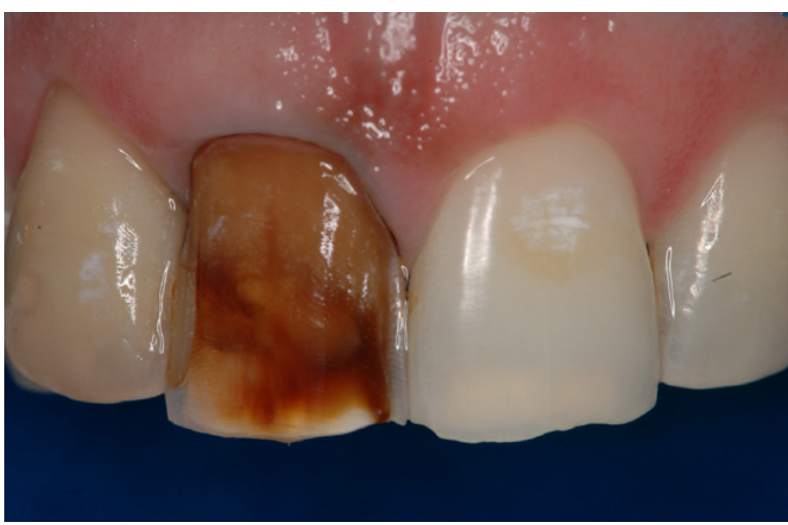

Figure 3. Dental prepared

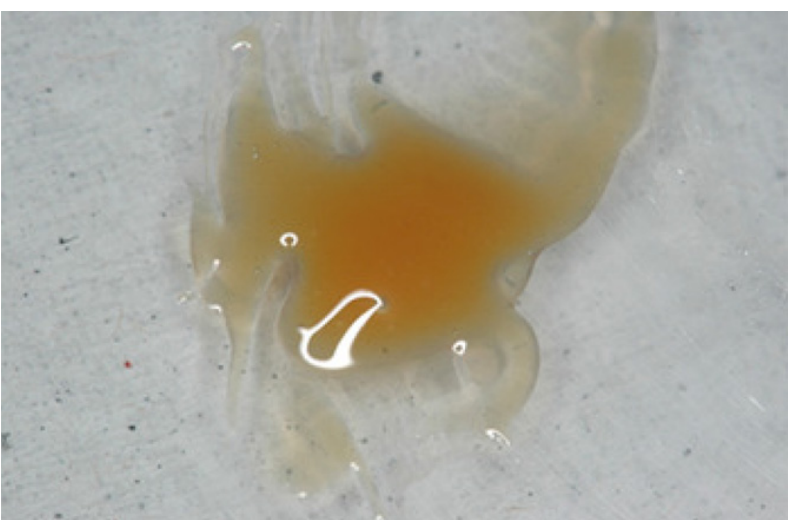

Figure 5. Pigment applied over the layer of opaque resin
Sof-lex pop on (3M), and silicone tips Astropol (IvoclarVivadent, Barueri, SP, Brazil) were used to create esthetic surface texture.

One week later, after tooth rehydration, composite resin final polymerization and water sorption, final finishing and polishing were performed (Figure 6). Polishing paste Enamelize (Cosmedent INC-Chicago, Ilinóis, EUA) was also used with the aid of a felt buff to provide final surface luster and shine.

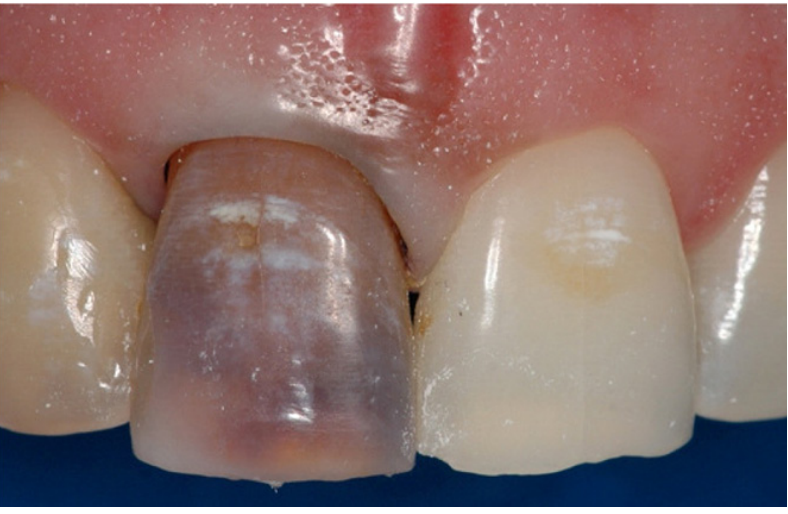

Figure 2. Modified absolute isolation and insertion of the retractor cord.

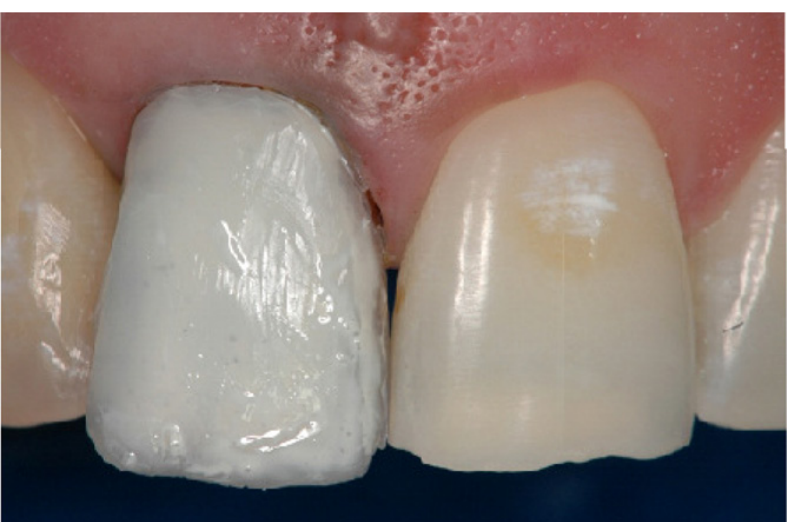

Figure 4. Application layer of opaque resin

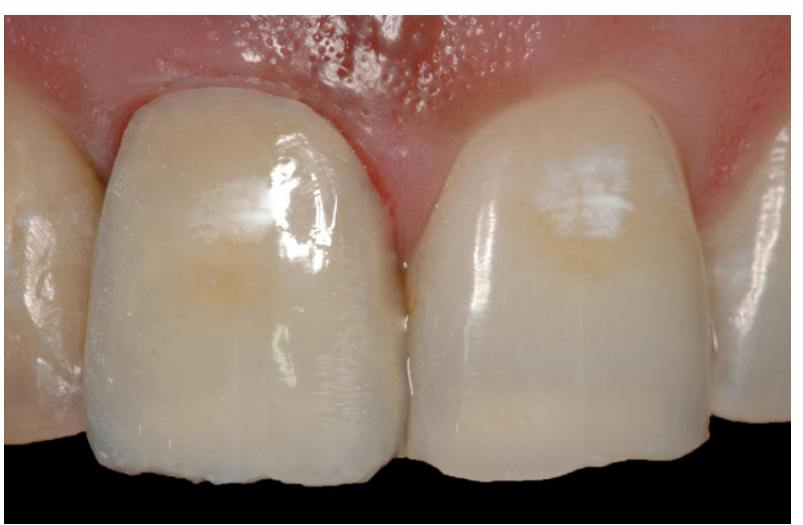

Figure 6. Final appearance after finishing and polishing of the right central incisor. 


\section{DISCUSSION}

The observation of dental anatomy and the development of dental materials allowed the clinician to optically mimic natural tissues, giving the way to map and predict the success of reproduction of tooth details.

The restorative treatment reported was of great value because, among other relevant factors, patient satisfaction was guaranteed, restoring his smile naturally. Khan \& Fida [2], 2008 verified in their studies with 120 adults examined that there is a strong psychosocial impact in the emotional state of individuals, due to the esthetic alteration of the teeth. Poyser et al. [7], 2004 also reports that discolored and non-vital anterior tooth is a common esthetic concern that can have a profound effect on patient's self-esteem.

The study of colors and dental structures combined with a correct choice of dental materials enables a proper interaction between the tooth structures and restorative materials. With the implementation of a thorough technique, the restoration achieves a predictable and satisfactory final esthetic result.

The great importance of esthetics in dentistry has gained highlight and the composite resin appears as a direct primary for the restoration of esthetics and function of the remaining teeth. Natural teeth have opalescence, translucency and fluorescence, all of which must be replicated by restorative materials in order to achieve clinical success. The shades and color variation deliver a more faithful reproduction of the chromaticity and translucency/opacity of enamel and dentin [8]. The development of pigments, opaque, translucent and fluorescent composite resins, offer ranges of options for characterization and individualization of direct restorations.

The case reported showed that the characterization of the tooth through the use of pigments was crucial for the establishment of esthetic harmony, as only one tooth had severe discoloration as a result of endodontic treatment.

Discolored non-vital teeth are often related to previous trauma, caries, endodontic therapy and failed restorations. Destructive invasive treatment options are likely to weaken the remaining structure of tooth [7]. In some cases, teeth that are severely discolored and pigmented for many years may have an unfavorable prognosis for tooth bleaching. Therefore, Zappala et al. [3], 1994, point laminate veneers, all-ceramic crowns and metal-ceramic crowns as options for treatment of discolored and malformed teeth.

Respecting the principles of conservative philosophy, dental treatment was employed in a more conservative technique, as minimum wear on the buccal surface was performed. The reduced wear favored the tooth structure that had already been weakened as a result of wear made to perform endodontic treatment.

Felippe et al. [9], 2003 describe that composite resin can be used to conservatively resolve many esthetic problems. Opaque resins can be used in many cases to mask discolorations or to characterize the teeth. By employing a direct restorative technique, the use of opacifiers can be a great supporting procedure when performed in anterior restorative procedures.

The use of pigments as reported in the clinical case, helped in characterizations of tooth associated with a smaller wear of dental structure. Smaller thickness of restorative material was necessary, because the thickness of pigment is less than the amount of composite resin needed to produce the same effect.

Another important aspect related to the use of pigments was the chance of reproduction of natural and particular characteristics on the labial surface of incisors. It was observed that only the insertion of composite resin for the reproduction of hue, chroma and value of the homologous tooth was required. Blank [4], 2006 indicates that success and predictable outcome of treatment depends on the clinician's understanding of the material properties. The identification of the natural tooth features is also important.

The harmonization of the primary parameters in esthetics such as color, shape and texture is a challenge for the restoration of anterior teeth. Tooth preparation, development of body layer, internal characterization with tints, insertion of artificial enamel layer, shape and polishing are important considerations that ensures an optimal esthetic outcome for direct restoration [6].

For restorative procedures during this reported clinical case, microhybrid composite resin were used. Microhybrid resins have been associated with enhanced polishability. The development of properties of these materials helped to reduce the staining and the accumulation of plaque, minimizing wear and improving the final appearance of the final restoration [10].

The esthetical dental reproduction creating surface texture and contour resulted from a correct finishing and polishing of direct restoration. In an indirect restoration careful finishing and polishing is done in the laboratory, therefore, great attention must be given by clinician so that this step is not neglected. This requires that the professional knows how to choose the correct instruments and materials for carrying out the procedures for finishing and polishing [10].

\section{CONCLUSION}

It was concluded that when different restorative materials are employed, with careful observation and evaluation of dental structures, satisfactory results are achieved. Direct restorations performed with minimal wear of tooth structure can be a very effective technique for the esthetic reestablishment of the tooth.

\section{Clinical Considerations}

The proper use of various composite resins, with a careful technique is able to mimic the tooth structures. Combining all these factors with minimal intervention is possible in many cases, to opt for direct restorations rather than indirect restorations. 


\section{REFERENCES}

1. Davis LG, Ashworth PD, Spriggs LS. Psychological effects of aesthetic dental treatment. J Dent. 1998;26:547-54.

2. Khan M, Fida M. Assessment of psychosocial impact of dental aesthetics. J Coll Physicians Surg Pak. 2008;18:559-64.

3. Zappala C, Bichacho N, Prosper L. Options in aesthetic restorations: discoloration and malformation - problems and solutions. Pract Periodontics Aesthet Den. 1994;6:43-52

4. Blank JT. Creating translucent edge effects and maverick internal tints using microhybrid resin. Pract Proced Aesthet Dent. 2006;18:131-6.

5. Blank JT. Simplified techniques for the placement of stratified polychromatic anterior and posterior direct composite restorations. Compend Contin Educ Dent. 2003;24:19-25

6. Terry DA. Dimensions of color: creating high-diffusion layers with composite resin. Compend Contin Educ Dent. 2003;24:3-13.
7. Poyser NJ, Kelleher MG, Briggs PF. Managing discoloured non-vital teeth the inside/outside bleaching technique. Dent Update. 2004;31:204-10 213-4

8. Villarroel M, Fahl N, De Sousa AM, De Oliveira OB, Jr. Direct esthetic restorations based on translucency and opacity of composite resins. J Esthet Restor. Dent;23:73-87.

9. Felippe LA, Monteiro S, Jr., Baratieri LN, Caldeira de Andrada MA, Ritter AV. Using opaquers under direct composite resin veneers: an illustrated review of the technique. J Esthet Restor Dent. 2003;15:327-37.

10. Morgan M. Finishing and polishing of direct posterior resin restorations. Pract Proced Aesthet Dent. 2004;16:211-8.

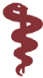

